\title{
Admitting an Attraction: Colonial Villainy, Visuality, and The Handmaiden (2016) as Critique
}

Keungyoon Bae*

2016's The Handmaiden is unusual among contemporary Korean films for more than one reason. Firstly, we have an explicitly queer, in fact erotically queer narrative from a country where LGBT rights are still very much a point of contention, especially in recent years (although there are grounds for optimism). Secondly, it is a South Korean film that has received a substantial amount of attention from European and American media; while Korean films have certainly been making the rounds at film festivals and art house cinema circles for years, it is still relatively uncommon to see a Korean film break into the American mainstream in terms of marketing and distribution, and receive coverage in publications as varied as The New Yorker, ${ }^{1}$ Indiewire, ${ }^{2}$ and Gawker (now Gizmodo)

* PhD Student, East Asian Languages and Civilizations, Graduate School of Arts and Sciences, Harvard University.

1 Jia Tolentino, "'The Handmaiden and the Freedom Women Find Only with One Another," The New Yorker, October 29, 2016. Web. Accessed February 13, 2017. <http://www.newyorker.com/culture/jia-tolentino/the-handmaiden-and-thefreedom-women-find-only-with-one-another>

2 Eric Kohn. 'Cannes Review: 'The Handmaiden' is a Sexy and Depraved Lesbian Revenge Story from Park Chan-wook," Indiewire, May 15, 2016. Web. Accessed February 13, 2017. <http://www.indiewire.com/2016/05/cannes-review-the-handm aiden-is-a-sexy-and-depraved-lesbian-revenge-story-from-park-chan-wook-290562/> 
Media's Jezebel. ${ }^{3}$ (The Handmaiden was a few years before the landmark film Parasite would claim multiple awards at the Oscars.) Thirdly, it is an adaptation of the novel Fingersmith by a Welsh novelist Sarah Waters, and the film transports the original work's Victorian settings to 1930s colonial Korea, a process that one must assume required a significant leap of the imagination.

My focus in this analysis is not on any of the points mentioned above, though each of them, I am sure, would yield its own fascinating paper. I would like to focus on the film's function as both an example and a critique of contemporary South Korean media's flirtation with the colonial period, and how its complex framing of erotica, eroticism, and female intimacy directly relate to that critique.

In order to expand upon the ways in which The Handmaiden engages and subverts pre-existing tropes in contemporary/2000s Korean cinematic representation of the colonial era, I must first establish that context. Each year, there have been glossy, high-budget films and television shows that portray the colonial era, ${ }^{4}$ many of which have found popular success: as of 2020, Choi Dong-hoon's 2015 film Assassination is the eleventh highest grossing film in South Korean history, ${ }^{5}$ and Kim Ji-woon's Warner Brothers-funded 2016 film Age of Shadows attracted approximately 7.5 million filmgoers and became the fourth highest grossing film of the year, just behind Captain America: Civil War. ${ }^{6}$ The 2012 TV series Gaksital

3 Kelly Faircloth, "The Handmaiden is a Twisty, Sexy, Gothic Tale of Suspense," Jezebel Gawker Media, October 21, 2016. Accessed February 13, 2017. < http://themuse.jezebel.com/the-handmaiden-is-a-twisty-sexy-gothic-tale-ofsuspen-1788061031>

4 The colonial era lasted from 1910 to 1945, from when Japan officially annexed Korea (then called Chosŏn) until the end of the Second World War; August 15, 1945, in South Korea, is Independence Day.

5 "Historical Box Office (Integrated network aggregate)," Korean Film Council. Web. Accessed June 22, 2020. <http://www.kobis.or.kr/kobis/business/stat/boxs/fin dFormerBoxOfficeList.do>

6 "South Korea Yearly Box Office, 2016." Box Office Mojo, IMDb. Web. Accessed 
("Bridal Mask"), based on a popular comic book by Hur Young Man and which follows the adventures of a double-agent working as both an imperial policeman and a Korean resistance fighter/assassin, finished its 28episode run with high ratings of 22.9 percent; ${ }^{7}$ the 2007 series Capital Scandal, which portrays the conversion of a modern Casanova into a patriotic resistance fighter, did not record such high ratings, but developed a cult following fan-base.

In Parameters of Disavowal: Colonial Representation in South Korean Cinema, An Jinsoo points out that representations of the colonial past in Korean cinema have often been overlooked by scholars, as they were "dismissed as middlebrow cultural productions that have functioned to organize the larger precepts of political ideology in understandable terms." "While most of his book is concerned with the ways in which Cold War ideologies were refracted in colonial-era representations, I think post-2000s films have likewise been dismissed as popular, mainstream works that valorize and memorialize colonial-era anti-Japanese resistance, fulfilling their role as stirring, swashbuckling escapist entertainment.

The films and TV shows I have mentioned above are but a few of the most notable examples, but I would argue that by and large these works operate by certain rules. Firstly, they establish a binary of collaboration and resistance, where the obvious villains are the Japanese colonizers, and there is a clear, moral right and wrong: to resist the imperial forces and aid the fight for Korea's independence is always morally right, and to cooperate with the imperial government and thereby "selling out" your country's independence is always morally wrong. Those in between, who

February 13, 2017. <http://www.boxofficemojo.com/intl/korea/yearly/>

7 '"Bridal Mask' comes to an end with its highest viewer ratings." Allkpop, September 7, 2012. Web. Accessed February 13, 2017. < http://www.allkpop.com/article/ 2012/09/bridal-mask-comes-to-an-end-with-its-highest-viewer-ratings>

8 An Jinsoo, Parameters of Disavowal: Colonial Representations in South Korean Cinema (Oakland, California: University of California Press, 2018), 4. 
do not actively collaborate but live in deliberate complacency, also tend to be categorized as "wrong." Secondly, these films and television shows traffic in the visual attraction of modernity, specifically its capitalist allure. Korea was introduced to many of the trappings of modernity - trains, radio, photography, cinema - under the colonial rule, and this is to this day a point of contention in academic historical discourse and mainstream politics. Nevertheless, part of the attractive power exercised by these films and shows is their visual sumptuousness, the glamor of 1920s-1930s architecture, fashion, technology, and culture.

A form of nervous hypocrisy arises between these two positions. The films and TV shows tend to explicitly espouse a nationalist message, wherein the impetus - the driving desire - is to find agency in the era widely characterized as lacking in agency for Koreans. The date of annexation, August 29th, 1910, is literally named Kyŏngsulgukch' $i$, or "National Humiliation in the Year Kyŏngsul"" it is also commonly paraphrased as "the day we lost our country." What is highlighted in these media works are forms of resistance during this time, whether it be the Korean independence movement, the anarchist group Heroic Corps (Uiyeoldan 의열단), or the secret ways in which everyday citizens gathered funds for independence activists and sheltered them. By focusing on acts of resistance, and contrasting them with acts of collaboration, betrayal, and obedience, these narratives explicitly position themselves as the stories of (forgotten) heroes who fought to combat the Japanese villains.

On the other hand, however, the visual strategy that these films and TV shows often use to attract and seduce their viewers is that of the alluring modern. Even as they portray the pain and suffering of independence activists and resistance fighters, these works take care to fully take advantage of the capital of vintage glamor that this era can provide, be it the "new women" of the 1930s with their cloche hats and fur stoles, or the suited men with their sharp fedoras and stiff collars. Never mind that most of the populace during this time did not wear such clothes, and that such luxury could only be afforded by the financial and intellectual elite. You might die midway through the narrative, shot through the head by the 
police, but at least you'll look good as you fall to the ground in slow motion, in a flapper hat and long wool coat.

Take, for instance, 2015's smash hit Assassination. It's a sprawling, adventurous tale of a hitman squad formed from Manchurian exiles, employed by the militant Heroic Corps. This squad's mission objective in the film is to assassinate a key Japanese general, Kawaguchi. At one point, the female protagonist utters these words, "In Manchuria, we didn't fix our roofs when they leaked, we didn't fix our walls when they fell down. ${ }^{9}$ We were going to go back home once independence came, why fix it? Will independence come with the death of one or two people? I don't know. But we have to let them know that we are still fighting." 10 Assassination thus explicitly argues for the importance of continued resistance - however violent it may be - even in the face of seemingly impossible odds. The film also provides the stance of collaboration and complacent obedience in the form of the protagonist's twin sister, who defends the actions of their collaborationist father, saying, "Everyone lives like that here. Daddy is a good person." The film makes it clear, however, the inevitable fate of such complacency, when this twin sister is shot dead by that very father.

Even while enthusiastically following the exploits of die-hard resisters, however, Assassination is blatantly desirous in its gaze toward the modernity of Seoul, the camera's eye lingering hungrily over the spectacular sets constructed for the film. The film does not hesitate to offer such visual delights as the brightly lit night street, stylish young men and women dancing the cha-cha in a chic bar, the gilded balustrades and sparkling chandeliers of the grand Mitsukoshi department store. Indeed, the film

9 Many resistance fighters and independence activists took up residence in Manchuria during the colonial era. See: Andre Schmid's Korea Between Empires, 18951919 (Columbia University Press, NY. 2002) and Lee Chongsik's Counterinsurgency in Manchuria: The Japanese Experience, 1931-1940 (Santa Monica, Calif., Rand Corp. 1967).

10 Assassination. Dir. Choi Donghoon. Caper Film, 2015. (Translation mine) 
does its best to get its money's worth out of the department store set, in that it sets the pivotal scene of the two twin sisters crossing paths in the store, and later at the same location stages a wedding. The wedding serves as the bloody, bullet-riddled climax of the film, a distinctly Hollywoodstyle spectacle of destruction that revels in the slow-motion collapse of staircases and splintery explosions of wood. By a rough estimation, the film spends approximately 20 minutes just in this department store.

Even as these media works chide the audience for forgetting the resistors and condoning the collaborators, they do not allow us to take our eyes off the sumptuous beauty of modernity and its attractions. In attempting to highlight and honor the resistance - at least on a narrative level - these media works also simultaneously fetishize the modern, in the classic sense of the term in that modernity is isolated from its militaryimperial context: the biopower and exploitation required to achieve modernity, and the utilitarian rationale of modernizing a colony. These contexts are ultimately obscured by the sentimental fade to sepia at the end, which make clear the audience's relationship - temporally and emotionally - to the history of the resistance; the final episode of the TV series Capital Scandal, for example, literally closes with a faded photograph of the main cast (without the villains), captioned, "Love freely and be happy in this precious land left to us by those who came before." (Fig. 1)

Even the final scenes of Assassination are the protagonist's wistful, nostalgic remembrance of her comrades as enshrouded in the modern: in a beautiful café in Shanghai, in the chic Seoul bar amongst drunk revelers, dancing the cha-cha. Bound by political and moral judgment, these films are inexorably attracted to the era but terrified of acknowledging intimacy. This contradiction reflects Korea's conflicted relationship with the modernity that infiltrated its history in an oppressive, imperialist context, in which the flourishing modern culture existed intimately with the issue of the "loss of country." Aimee Nayoung Kwon, in her book Intimate Empire: Collaboration and Colonial Modernity in Korea and Japan, has argued that it is precisely the acknowledgment of such intimacy that is necessary to "cut across the impasses of imperial and nationalist binary 


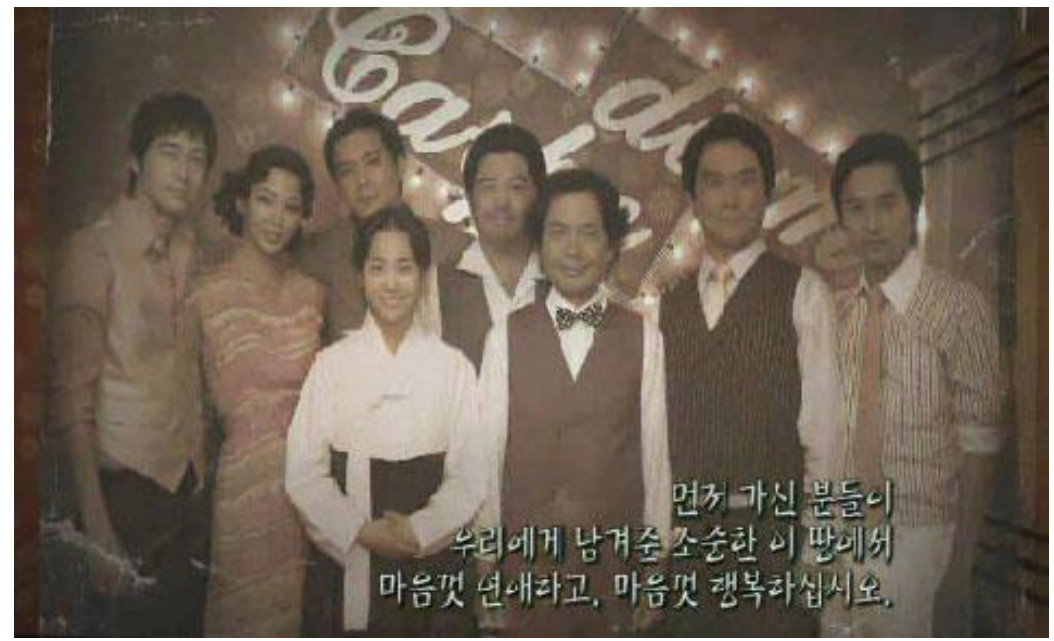

Fig. 1. The final image of the TV series Capital Scandal

rhetoric to redefine intimacy as an unstable play of affects informed by desire, longing, and affection - all of which coexisted with the better known violence and coercion undergirding empire."11 Korean films such as Assassination attempt to avoid engaging with that question precisely by visually fetishizing modernity and situating the nationalist ideology entirely outside the framework of such modernity, which then isolates and decontextualizes it from its historical and ideological connections.

\section{Regarding the Handmaiden's "Gaze"}

Keeping these two conflicting elements in mind, let us now consider how Park Chan-wook's The Handmaiden engages with contemporary Korean media's treatment of the colonial era. The Handmaiden, which largely follows the original novel's lead, tells the tale of Sukhui, a Korean

11 Kwon Aimee Nayoung, Intimate Empire: Collaboration and Colonial Modernity in Korea and Japan (Durham: Duke University Press, 2015), 8. 
pickpocket, who is brought in on a scheme to swindle a rich Japanese heiress, Hideko, out of her fortune. The plot's architect, a Korean grifter posing as a Japanese count (Count Fujiwara), directs Sukhui to become Hideko's handmaiden and help sway Hideko to fall in love with Fujiwara so that Fujiwara and Sukhui can collect her fortune and shut Hideko in an insane asylum. The plan hits an unexpected hurdle when the maid and her mistress find themselves falling for each other, and as the film retells the narrative from different perspectives, we find that all the characters are more complex than they seem. ${ }^{12}$

I cannot hope to do justice to the myriad intricacies and details of the film in this short paper, but I would like to bring your attention to the way in which the film can serve as a critique of certain traits found in the contemporary Korean media that I have illustrated above. There are some obvious ways in which the film differs from other mainstream films set in the colonial period. Firstly, it does not rely on the collaborationistresistance binary. None of its characters are valorized for anti-Japanese resistance, and none of the antagonists are viewed as villainous specifically for their turncoat nature. It is also one of the few - perhaps the only 2000s mainstream media work that portrays a colonial-era love story between a Japanese person and a Korean person. And in that both parties are female, the film manages to avoid the problem of creating a power dynamic through gendered national allegory within the romantic relationship. This explicit, unapologetic queerness of the narrative is yet another level of subversion for a South Korean film, ${ }^{13}$ particularly in that the film

12 The Handmaiden. Dir. Park Chanwook. Moho Film, 2016.

13 Park, in an interview with Jezebel's Rick Juzwiak, points out the significance of the film's box-office success in a country where same-sex marriage is yet to be legalized, and anti-discrimination measures to protect LGBT people are facing significant pushback from Christian organizations. (Rich Juzwiak, "A Chat with Park Chan-wook about Adapting Sarah Waters's Fingersmith into the Lesbian Thriller The Handmaiden," Jezebel. Gawker Media, October 24, 2016. Web. Accessed February 13, 2017. <http://themuse.jezebel.com/a-chat-with-park-chan-wook-abou t-adapting-sarah-waterss-1788068479>) 
is not a narrative of coming out and acceptance, but rather one where the characters embark on their journey without feeling obliged to explain their queerness.

But what about the visuality of The Handmaiden? While the extravagance of the set is clearly a major component of the film, one of the key elements that sets The Handmaiden apart from its peers is the sophistication of its visual strategy. I argue that the film has a strong awareness of the fact that modernity as it developed in Korea was a mediated modernity, brought in by way of Japan, and consequently with certain political and ideological strings attached. The reality of Korean modernity is metaphorically represented by the Kōzuki mansion: both English (Western) and Japanese, splendid yet sinister, massive yet stifling. It is worth noting that Sasaki, the mansion's housekeeper, proudly touts the mansion's Japanese-English dual character, but refrains from mentioning the Korean architecture of its servant quarters. The film presents Hideko's fine clothing and accessories in luscious detail, with Sukhui savoring the moment as she undoes the many buttons to Hideko's dress: "Ladies truly are the dolls of maids. All these buttons are for my amusement." Yet in the second act, we realize that Hideko has been purposefully parading her finery in front of Sukhui, per the advice of Fujiwara (the viewers are made to think that he has secretly been plotting with Hideko against Sukhui in a double-cross scheme). "Show Sukhui your clothes and jewelry at every opportunity," he writes to Hideko. "The material greed she got from her mother will make her more gullible." Thus, visual attraction in the world of The Handmaiden is never innocent, and comes at a price; even the blossoms of Kouzuki's cherry tree are stained with blood, Hideko points out, as they "turned brighter and bloomed longer" after Hideko's aunt hanged herself from its branches. Unlike films like Assassination, which feature isolated fetishizations of modernity, The Handmaiden employs metonymy and synechdoche as key strategies, which urge the viewers to recognize that the film's beautiful visuals cannot be dissociated from the darkness of colonial modernity, misogyny, and perversion.

But perhaps the most subversive element of the film is its engagement 
with erotica. The film's second act shows us Hideko's upbringing by her uncle Kōzuki, who grooms her to be a virtuosic reader of his prized erotic novels, as in, she is trained to read them aloud to an audience. This act of the film establishes erotica as a major element of Hideko's oppression, a device that pins her under the gaze of Kōzuki's male guests as they all partake in her performance. She is relegated to the role of mannequin or prop within their male fantasies; at one point the film literalizes her circumstances by showing her demonstrating a sex position with a mannequin to provide visual aid for the guests.

Yet it is also in this second act that we see Hideko's relationship with erotica changing. During one performance of the novel "The Sound of Bells on a Windless Night," the mansion goes through a brief blackout, and for a short while, Hideko is able to be alone with the material that she reads. In the dark, she closes her eyes as she narrates the story, without even needing to read the pages, describing the lovemaking between a lady and her maid; we see, for the first time, Hideko mining her own pleasure from the act of reading, as she is granted a brief respite from the voracious male gaze. In the scene immediately following, we observe Hideko and Sukhui's lovemaking. We are seeing this moment for the second time in the film, as we have already seen it from Sukhui's point of view in the first act; this time around, however, we realize that Hideko is not as inexperienced as she appeared before, but is instead attempting to explore and reenact the material that she read in "The Sound of Bells." In a New Yorker review, Jia Tolentino points out that it is in this scene that the normally reserved Hideko "produces her most-perhaps her only-unfettered smile." 14

While I recognize that The Handmaiden's sex scenes have (understandably, and rightfully) faced criticism for its failure to excise a male gaze quality in how they were filmed, I find that there are still cathartic and liberating qualities here, not from the consummation itself, but from

14 Jia Tolentino, “"The Handmaiden and the Freedom Women Find Only with One Another." 
the act of appropriation. The enactment of erotica, which occurs once again at the end of the film as Hideko and Sukhui experiment with sex toys on a ship to Shanghai, could be seen as a live illustration of male fantasy, but I would argue that it could also just as easily be viewed as female appropriation of erotic material for female pleasure. The fact of the material's origins in patriarchal oppression does not de-legitimize the pleasure that the female characters derive from it. And this liberating potential of appropriation is signaled throughout the film; for instance, the noose that signifies the tragic death of Hideko's aunt (Kōzuki's first wife) later becomes an opportunity for a revelatory moment, where Hideko and Sukhui confess their true intentions and feelings. The many buttons and sashes that bind women's bodies beneath their clothes transform into erotic pleasure as Sukhui dresses and undresses her mistress. The silver bells that the women use as sex toys are reminiscent of the metal balls that Uncle Kōzuki uses to punish young Hideko for her disobedience. These moments of liberation are never dissociated from the shadows of tragedy and oppression, thanks to the film's careful visual echoes: of Hideko's aunt (hanging from the tree) to Hideko herself (attempting to hang herself), of the curious erotic statuette in the library to the final sex position in which we see Hideko and Sookhee.

Appropriation, here, is inherently a process of recognizing oppressive circumstances. When Sukhui and Hideko appropriate erotica, the act is in full cognizance of the oppressive origins of that material, and part of the liberation comes from the subversion of those oppressive origins. And this is where I find that The Handmaiden can provide a new vision for moving forward in contemporary imaginings and understandings of the colonial era. The film shows us that we can address oppressive systems as the film does, decisively, in destroying Kōzuki's erotica library - but also that we can move forward from it through acts of appropriation. Indeed, when attempting to approach a kind of truth about the time period, it is imperative that media and cultural works challenge the kind of hypocrisy that I have previously detailed, in which we constantly excavate individual acts of valor without further examining the more complex is- 
sues of modern development under oppression; in which we make a visual spectacle of resistance during modernity, even while ignoring the ominous implications of our visual susceptibility to modernity's allure. I find it no coincidence that it is an explicitly queer and feminist - if flawed media work that awakens us to this hypocrisy, and furthermore provides us with a forward-looking vision.

\section{Works Cited}

1. An, Jinsoo. Parameters of Disavowal: Colonial Representations in South Korean Cinema, Oakland, California: University of California Press, 2018

2. Kwon, Aimee Nayoung, Intimate Empire: Collaboration and Colonial Modernity in Korea and Japan, Durham: Duke University Press, 2015

3. Tolentino, Jia. "'The Handmaiden' and the Freedom Women Find Only with One Another," The New Yorker. October 29, 2016. Web. Accessed February 13, 2017.

4. <http://www.newyorker.com/culture/jia-tolentino/the-handmaidenand-the-freedom-women-find-only-with-one-another>

5. "Historical Box Office (Integrated network aggregate)," Korean Film Council. Web. Accessed June 22, 2020.

6. <http://www.kobis.or.kr/kobis/business/stat/boxs/findFormerBoxOffi ceList.do>

7. "South Korea Yearly Box Office, 2016." Box Office Mojo, IMDb. Web. Accessed February 13, 2017. <http://www.boxofficemojo.com/ intl/korea/yearly/>

8. "Bridal Mask' comes to an end with its highest viewer ratings." Allkpop. September 7, 2012. Web. Accessed February 13, 2017. < http://www.allkpop.com/article/2012/09/bridal-mask-comes-to-anend-with-its-highest-viewer-ratings>

9. Assassination. Dir. Choi Dong-hoon. Caper Film, 2015. 
10. The Handmaiden. Dir. Park Chan-wook. Moho Film, 2016.

11. Juzwiak, Rich. "A Chat with Park Chan-wook about Adapting Sarah Waters's Fingersmith into the Lesbian Thriller The Handmaiden." Jezebel. Gawker Media, October 24, 2016. Web. Accessed February 13, 2017. < http://themuse.jezebel.com/a-chat-with-park-chan-wookabout-adapting-sarah-waterss-1788068479> 
